\title{
Clinical features of 27 Turkish Propionic acidemia patients with 12 novel mutations
}

\author{
Deniz Kör ${ }^{1}$, Berna Şeker-Yılmaz ${ }^{2}$, Fatma Derya Bulut ${ }^{3}$, Sebile Kılavuz ${ }^{1}$, Murat Öktem ${ }^{4}$, \\ Serdar Ceylaner ${ }^{5}$, Dinçer Yıldızdaş ${ }^{6}$, Neslihan Önenli-Mungan ${ }^{1}$ \\ Divisions of ${ }^{1}$ Pediatric Metabolism and Nutrition, and ${ }^{6}$ Pediatric Intensive Care Unit, Çukurova University Faculty of \\ Medicine, Adana; ${ }^{2}$ Department of Pediatric Metabolism, Mersin City Hospital, Mersin; ${ }^{3}$ Department of Pediatric \\ Metabolism, Adana City Hospital, Adana; ${ }^{4}$ Düzen Biochemistry Laboratories, Ankara; 5 Intergen Genetics Laboratories, \\ Ankara, Turkey. E-mail: dozonur@yahoo.com
}

Received: 16th February 2019, Revised: 1st April 2019, Accepted: 3rd April 2019

SUMMARY: Kör D, Şeker-Yılmaz B, Bulut FD, Kılavuz S, Öktem M, Ceylaner S, Yıldızdaş D, Önenli-Mungan N. Clinical features of 27 Turkish Propionic acidemia patients with 12 novel mutations. Turk J Pediatr 2019; 61: 330-336.

Propionic acidemia (PA) is an inherited metabolic disease caused by the deficiency of one of the four biotin-dependent enzymes propionyl-CoA carboxylase (PCC), and is characterized by coma and death in unrecognized patients, additionally late diagnosis leads to severe developmental delay and neurological sequels. Manifestations of PA over time can include growth impairment, intellectual disability, seizures, basal ganglia lesions, pancreatitis, and cardiomyopathy. Other rarely reported complications include optic atrophy, hearing loss, premature ovarian insufficiency, and chronic renal failure. Mutations in PCCA-PCCB genes cause the clinically heterogeneous disease of PA. In this study, we investigate the mutation spectrum of PCCAPCCB genes and phenotypic features of 27 Turkish patients with PA from the South and Southeast parts of Turkey. We report 12 novel PA mutations, five affecting the PCCA gene and 7 affecting the PCCB gene.

Key words: Propionic acidemia, novel mutation, clinical features, PCСA, РССВ.

Propionic acidemia (PA; MIM\# 232000 and $232050)$ is an autosomal recessive inherited metabolic disorder caused by the deficiency of the mitochondrial biotin-dependent enzyme propionyl-CoA carboxylase (PCC), which catalyzes the conversion of propionyl coenzyme A (propionyl-CoA) to methylmalonylcoenzyme A (methylmalonyl-CoA). ${ }^{1}$ PCC is essential for the catabolism of the branchedchain amino acids, odd-numbered fatty acids, cholesterol, and other metabolites. ${ }^{2}$ The PCC holoenzyme is a dodecamer composed of an equal number of alpha and beta subunits. ${ }^{3}$ The alpha subunit is encoded by the PCCA gene (chromosome 13q32, MIM\#232000). The beta subunit is encoded by the $P C C B$ gene (chromosome 3q13.3-q22, MIM\#232050). ${ }^{4}$ Mutations in either the PCCA or PCCB gene cause PCC deficiency. To date, 149 mutations in the PCCA gene and 131 in the PCCB gene have been collected in the Human Genome Mutation Database (HGMD ${ }^{\circledR}$ Professional 2018.4). The PCC deficiency results in increased amounts of diagnostic intermediates of methylcitrate, 3-hydroxypropionate and propionylcarnitine in urine and plasma. ${ }^{5}$ The clinical features of PA are highly heterogeneous. Affected patients most commonly present in the neonatal period. Vomiting, refusal of feeding, dehydration, lethargy, hypotonia, seizures, metabolic acidosis, hyperammonemia, and hypoglycemia are the prominent signs and symptoms of the disease. The clinical picture can quickly progress to coma and death in unrecognized patients, however late diagnosis leads to severe developmental delay and neurological sequelae. ${ }^{6-7}$ Additionally, chronic complications of PA may affect the whole body with neurological, cardiologic, hematologic, immunologic, endocrine, and gastrointestinal 
manifestations. ${ }^{8}$ Therefore, early diagnosis and proper treatment are crucial. The main principles of PA treatment consist of proteinrestricted diet, carnitine supplementation, and prevention of catabolism in fasting situations.

In this study, we investigate the mutation spectrum of PCCA-PCCB genes and phenotypic features of 27 Turkish patients with PA from the South and Southeast parts of the country.

\section{Material and Methods}

We conducted a retrospective study of patients with PA at Çukurova University Faculty of Medicine, Department of Pediatric Metabolism and Nutrition. Twenty-seven patients with PA, who came from 21 unrelated families were included in this study. All the patients were diagnosed with the clinical features confirmed by urine organic acid analysis and gas chromatography-mass spectrometry (GC-MS) and not through a neonatal screening program (NSP). Clinical diagnosis was confirmed by PCCA and PCCB genes analysis. PCCA and $P C C B$ genes sequence analysis was performed by using MiSeq next generation sequencing (NGS) platform (Illumina, San Diego, CA, USA). The Ethics Committee of the Cukurova University Faculty of Medicine approved this study (Approval number: 2017/85-52).

\section{Mutation Analyses of PCCA and PCCB genes}

Genomic DNA was extracted according to the manufacturer's standard procedure using the Anatolia Magnesia Blood Kit (Anatolia Geneworks, Turkey). All coding exons and their flanking splice site junctions were amplified using PCR primers, designed with PRIMER $^{\odot}$ - Primer Designer v.2.0 (Scientific \& Educational Software programme) software. Next-generation sequencing was carried on MiSeq (Illumina Inc. (Illumina, San Diego, CA, USA)) Sequences were aligned to the hg19 genome within MiSeq Reporter software (Illumina Inc.). Visualization of the data was performed with IGV 2.3 (Broad Institute, Cambridge, Massachusetts) software.

Mutations were screened in the literature. In silico analysis of the variations was done with Varsome software. Variants were also checked in 2500 exome sequencing data of our patients. This data is of patients applied to our Intergen Genetics Center for diagnostic purposes. HiSeqControl Software, CLC Bio Genomics Workbench, SeattleSeq Annotation was used for analysis.

\section{Results}

The frequently observed initial symptoms, signs and laboratory findings that lead to PA diagnosis were feeding difficulties (48.1\%), asymptomatic with family history of PA $(40.7 \%)$, vomiting $(37 \%)$, tachypnea $(37 \%)$, hypotonia $(26 \%)$, lethargy $(14.8 \%)$, seizures $(11.1 \%)$, pancytopenia $(7.4 \%)$, hypoglycemia $(3.7 \%)$, and feeding refusal $(3.7 \%)$. Patients' characteristics and clinical data are presented in Table 1. In this study, most of the parents (96.3\%) were consanguineous. Positive family history rate was 19/27 (70.4\%). The current age of the patients ranged from 0.3 35.6 years. The age at onset of symptoms was from birth to 18 months (median:3 days, mean: $40.44 \pm 108.8$ ), and the age of diagnosis ranged from the prenatal period to 10.5 years (median: 35.5 days, mean: 295.12 \pm 828.3 days). Nineteen patients became symptomatic within the first 10 days of life, 4 patients within 10-30 days of life, and the remaining 4 patients in the second month of life. Twentytwo patients had severe clinical phenotype, and the remaining five patients had milder phenotype. Seventeen patients (63\%) were still alive, while 10 patients had died during an acute metabolic crisis. Metabolic acidosis was reported in 23 patients, and 16 out of 23 patients had hyperammonemia (Table I). Hyperammonemia was seen as high as in urea cycle defects. The highest concentration found in our study cohort was $>1000 \mu \mathrm{mol} / \mathrm{L}$. Pancytopenia was found in six patients and creatine kinase levels were increased in six patients (Table II). A total of 12 different PCCB and 8 different $P C C A$ gene mutations were identified (Table III), of which 12 were novel. Only one same mutant allele was identified in two unrelated patients (patient 16-26). Different mutations were detected in all other patients. No genotype-phenotype correlations were found. 
Table I. Clinic Features of Patients.

\begin{tabular}{|c|c|c|c|c|c|c|c|}
\hline $\begin{array}{l}\text { Patient } \\
\text { no }\end{array}$ & $\begin{array}{l}\text { Current } \\
\text { age } \\
\text { (years) }\end{array}$ & Sex & Consanguinity & $\begin{array}{l}\text { Abnormality } \\
\text { in family } \\
\text { history }\end{array}$ & $\begin{array}{l}\text { Age at onset } \\
\text { /age at } \\
\text { diagnosis }\end{array}$ & & $\begin{array}{l}\text { Clinical } \\
\text { phenotype }\end{array}$ \\
\hline $\begin{array}{l}1 * \operatorname{sib} \\
\text { of } 2\end{array}$ & 0.3 & M & $\mathrm{Y}$ & $\mathrm{Y}$ & Prenatal & Prenatal & Severe \\
\hline $\begin{array}{l}2^{*} \operatorname{sib} \\
\text { of } 1\end{array}$ & Ex & $\mathrm{F}$ & Y & $\mathrm{Y}$ & $3 \mathrm{~d} / 55 \mathrm{~d}$ & $\begin{array}{l}\text { Hypotonia,feeding difficulties, seizures, } \\
\text { pansitopenia }\end{array}$ & Severe \\
\hline 3 & 3.3 & M & $\mathrm{Y}$ & $\mathrm{N}$ & $13 \mathrm{~d} / 56 \mathrm{~d}$ & $\begin{array}{l}\text { Hypotonia,feeding difficulties, lethargy, } \\
\text { tachypnea }\end{array}$ & Severe \\
\hline 4 & 13.8 & M & $\mathrm{Y}$ & $\mathrm{Y}$ & $6 \mathrm{~m} / 7 \mathrm{~m}$ & Vomiting, seizures & Mild \\
\hline $\begin{array}{l}5^{*} \mathrm{sib} \\
\text { of } 6\end{array}$ & 1.2 & M & $\mathrm{Y}$ & $\mathrm{Y}$ & $2 \mathrm{~d} / 5 \mathrm{~m}$ & Family scan & Mild \\
\hline $\begin{array}{l}6^{*} \mathrm{sib} \\
\text { of } 5\end{array}$ & 11.8 & $\mathrm{~F}$ & $\mathrm{Y}$ & $\mathrm{Y}$ & $18 \mathrm{~m} / 10.5 \mathrm{y}$ & $\begin{array}{l}\text { Feding refusal, cyclic vomiting related to } \\
\text { infections }\end{array}$ & Mild \\
\hline 7 & 35.6 & $\mathrm{~F}$ & $\mathrm{Y}$ & Y & $1 \mathrm{~m} / 6 \mathrm{y}$ & $\begin{array}{l}\text { Cyclic vomiting related to infections, } \\
\text { feding difficulties, after acute viral } \\
\text { hepatitis }\end{array}$ & Mild \\
\hline 8 & 3.3 & $\mathrm{~F}$ & $\mathrm{~N}$ & $\mathrm{~N}$ & $4 \mathrm{~m} / 1 \mathrm{y}$ & $\begin{array}{l}\text { Hypotonia, feding difficulties, lethargy, } \\
\text { metabolic acidosis }\end{array}$ & Severe \\
\hline $\begin{array}{l}9 * \text { sib of } \\
10\end{array}$ & 0.3 & M & $\mathrm{Y}$ & $\mathrm{Y}$ & $1 d / 3 d$ & Tachypnea & Severe \\
\hline $\begin{array}{l}10^{*} \operatorname{sib} \\
\text { of } 9\end{array}$ & Ex & M & $\mathrm{Y}$ & Y & $2 \mathrm{~d} / 7 \mathrm{~d}$ & Tachypnea, hypoactivity & Severe \\
\hline 11 & 5.5 & $\mathrm{~F}$ & $\mathrm{Y}$ & Y & $2 d / 25 d$ & Feeding difficulties, hypoactivity & Severe \\
\hline 12 & 6.8 & $\mathrm{~F}$ & $\mathrm{Y}$ & $\mathrm{N}$ & $3 \mathrm{~d} / 1 \mathrm{~m}$ & $\begin{array}{l}\text { Feeding difficulties, hypoglycemia, } \\
\text { metabolic acidosis }\end{array}$ & Severe \\
\hline 13 & 7.9 & M & Y & $\mathrm{N}$ & $1 \mathrm{~m} / 5 \mathrm{~m}$ & $\begin{array}{l}\text { Cyclic vomiting related to infections, } \\
\text { tachypnea, metabolic acidosis }\end{array}$ & Severe \\
\hline 14 & 2.1 & M & Y & $\mathrm{N}$ & $3 \mathrm{~m} / 4 \mathrm{~m}$ & Vomiting & Severe \\
\hline 15 & Ex & $\mathrm{F}$ & $\mathrm{Y}$ & $\mathrm{N}$ & $3 d / 25 d$ & $\begin{array}{l}\text { Feeding difficulties, metabolic acidosis, } \\
\text { hyperammonemia }\end{array}$ & Severe \\
\hline 16 & 2.5 & $\mathrm{~F}$ & Y & Y & $10 \mathrm{~d} / 6 \mathrm{~m}$ & Hypotonia, achypnea, family history & Mild \\
\hline 17 & Ex & $\mathrm{F}$ & $\mathrm{Y}$ & $\mathrm{Y}$ & $2 \mathrm{~d} / 5 \mathrm{~d}$ & Family history & Severe \\
\hline $\begin{array}{l}18^{*} \operatorname{sib} \\
\text { of } 19\end{array}$ & 12.1 & M & Y & $\mathrm{Y}$ & $3 \mathrm{~d} / \mathrm{NA}$ & Family history, vomiting & Severe \\
\hline $\begin{array}{l}19 * \text { sib } \\
\text { of } 18\end{array}$ & 3.6 & M & Y & Y & $3 \mathrm{~d} /$ prenatal & $\begin{array}{l}\text { Prenatal, vomiting, lethargy, metabolic } \\
\text { acidosis }\end{array}$ & Severe \\
\hline $\begin{array}{l}20^{*} \mathrm{sib} \\
\text { of } 21\end{array}$ & Ex & M & Y & $\mathrm{Y}$ & $3 \mathrm{~d} / 11 \mathrm{~d}$ & $\begin{array}{l}\text { Vomiting, feeding difficulties, metabolic } \\
\text { acidosis, lethargy }\end{array}$ & Severe \\
\hline $\begin{array}{l}21^{*} \operatorname{sib} \\
\text { of } 20\end{array}$ & 0.8 & $\mathrm{~F}$ & Y & $\mathrm{Y}$ & $3 d / 41 d$ & $\begin{array}{l}\text { Feeding difficulties, tachypnea, metabolic } \\
\text { acidosis, hyperammonemia, family } \\
\text { history }\end{array}$ & Severe \\
\hline $\begin{array}{l}22^{*} \\
\text { cousin } \\
\text { of } 23\end{array}$ & Ex & M & Y & $\mathrm{Y}$ & $9 d / 11 d$ & $\begin{array}{l}\text { Feeding difficulties, tachypnea, } \\
\text { hyperammonemia, family history }\end{array}$ & Severe \\
\hline $\begin{array}{l}23^{*} \\
\text { cousin } \\
\text { of } 22\end{array}$ & Ex & M & Y & $\mathrm{Y}$ & $3 \mathrm{~d} / 14 \mathrm{~d}$ & $\begin{array}{l}\text { Feeding difficulties, vomiting, tachypnea, } \\
\text { family history, dehydration }\end{array}$ & Severe \\
\hline 24 & Ex & $\mathrm{F}$ & Y & $\mathrm{Y}$ & $4 d / 10 d$ & Feeding difficulties, hypotonia, lethargy & Severe \\
\hline 25 & Ex & $\mathrm{F}$ & $\mathrm{Y}$ & Y & $1 d / 10 d$ & $\begin{array}{l}\text { Feeding difficulties, vomiting, tachypnea, } \\
\text { metabolic acidosis, pansitopenia }\end{array}$ & Severe \\
\hline 26 & 6.4 & $\mathrm{~F}$ & Y & $\mathrm{N}$ & $20 \mathrm{~d} / 6 \mathrm{~m}$ & Seizures & Severe \\
\hline 27 & Ex & M & Y & $\mathrm{N}$ & $2 \mathrm{~d} / 2 \mathrm{~m}$ & Tachypnea & Severe \\
\hline
\end{tabular}


Table II. Laboratory Findings of Patients.

\begin{tabular}{|c|c|c|c|c|c|}
\hline Patient no & $\begin{array}{l}\text { Metabolic } \\
\text { acidosis }\end{array}$ & Hyperammonemia & Hypotonia & Pancytopenia & CK level \\
\hline $1^{*} \mathrm{sib}$ of 2 & No & No & No & No & 575 \\
\hline $2^{*} \operatorname{sib}$ of 1 & Yes & No & Yes & Yes & 119 \\
\hline 3 & Yes & Yes $(>500)$ & Yes & No & \\
\hline 4 & Yes & Yes & No & No & \\
\hline $5^{*} \mathrm{sib}$ of 6 & No & No & No & No & \\
\hline $6^{*} \operatorname{sib}$ of 5 & No & No & No & No & \\
\hline 7 & Yes & No & No & No & 107 \\
\hline 8 & Yes & No & Yes & No & 250 \\
\hline $9^{*}$ sib of 10 & Yes & Yes & Yes & No & \\
\hline $10^{*}$ sib of 9 & Yes & Yes $(>500)$ & Yes & No & \\
\hline 11 & Yes & No & Yes & No & 99 \\
\hline 12 & Yes & Yes $(>500)$ & Yes & No & \\
\hline 13 & Yes & No & Yes & Yes & 101 \\
\hline 14 & Yes & No & Yes & No & \\
\hline 15 & Yes & Yes & No & No & \\
\hline 16 & No & No & Yes & No & 75 \\
\hline 17 & Yes & Yes & Yes & No & \\
\hline $18^{*} \mathrm{sib}$ of 19 & Yes & Yes & No & No & 129 \\
\hline $19 *$ sib of 18 & Yes & No & Yes & No & \\
\hline $20^{*} \mathrm{sib}$ of 21 & Yes & Yes & Yes & Yes & 808 \\
\hline $21^{*} \mathrm{sib}$ of 20 & Yes & Yes & Yes & No & 297 \\
\hline $22 *$ cousin of 23 & Yes & Yes $(>1000)$ & Yes & Yes & 117 \\
\hline $23^{*}$ cousin of 22 & Yes & Yes $(>1000)$ & Yes & No & 613 \\
\hline 24 & Yes & Yes $(>1000)$ & Yes & Yes & \\
\hline 25 & Yes & Yes & Yes & Yes & 88 \\
\hline 26 & Yes & Yes & Yes & No & 43 \\
\hline 27 & Yes & Yes & Yes & No & 744 \\
\hline
\end{tabular}

\section{Discussion}

In this report, we presented the clinical and molecular features of 27 Turkish PA patients from South and Southeast parts of Turkey which does not entirely represent the whole genotypic spectrum of PA in Turkey.

The clinical outcomes of the patients were evaluated and the disease-causing mutations were determined. Most of our PA patients' symptoms began in neonatal period and lateonset forms are rare. Of patients included in the study, $70.4 \%(19 / 27)$ became symptomatic within the first ten days of life. Other studies also reported early occurrence of symptoms as $71-92 \% .{ }^{9-11}$

The most common initial symptoms of PA patients were vomiting, feeding difficulties, feeding refusal, and failure to thrive. In our patient group also feeding problems, vomiting and feeding refusal were the most frequent manifestations (70\%), especially when compared with neurological signs. Although in some series, gastroenterological problems are more prominent at admission ${ }^{9,12-13}$, most 
Table III. Mutations of The Patients.

\begin{tabular}{|c|c|c|c|c|c|}
\hline Patient no & Gene & Exon/intron & $\begin{array}{l}\text { Nucleotide } \\
\text { change allele 1-2 }\end{array}$ & $\begin{array}{l}\text { Effect on codig } \\
\text { region allele } 1-2\end{array}$ & Reference \\
\hline $1^{*} \operatorname{sib}$ of 2 & PCCA & 19 & c. $1746 \mathrm{G}>\mathrm{A}$ & p.S582S & \\
\hline $2^{*} \mathrm{sib}$ of 1 & PCCA & 19 & c. $1746 \mathrm{G}>\mathrm{A}$ & p.S582S & \\
\hline 3 & РCCB & 15 & c. $1555 \mathrm{C}>\mathrm{T}$ & p.R519* & \\
\hline 4 & PCCA & 13 & c. $1209+3 \mathrm{~A}>\mathrm{G}$ & $\operatorname{IVS} 13+3 \mathrm{~A}>\mathrm{G}$ & \\
\hline $5^{*} \mathrm{sib}$ of 6 & PCCA & 4 & c. $424 \mathrm{C}>\mathrm{A}$ & p.T81N & This study \\
\hline $6^{*}$ sib of 5 & PCCA & 4 & c. $424 \mathrm{C}>\mathrm{A}$ & p.T81N & This study \\
\hline 7 & РССВ & 7 & c.C683T & p.P228L & \\
\hline 8 & РССВ & 2 & c. $207 \mathrm{G}>\mathrm{C}$ & p.R69S & This study \\
\hline $9 *$ sib of 10 & PCCA & 11 & c.843_843delT & p.N281Kfs*41 & This study \\
\hline $10^{*}$ sib of 9 & PCCA & 11 & c.843_843delT & p.N281Kfs*41 & This study \\
\hline 11 & PCCA & 16 & c. $1430-1 \mathrm{G}>\mathrm{A}$ & IVS16-1G >A & This study \\
\hline 12 & PCCA & 10 & c. $769 \mathrm{~A}>\mathrm{T}$ & p.R257* & This study \\
\hline 13 & РССВ & 13 & c. $1373 \mathrm{C}>\mathrm{T}$ & p.A458V & This study \\
\hline 14 & PCCA & 16 & c. $1412 \mathrm{~A}>\mathrm{T}$ & p.D471V & This study \\
\hline 15 & РССВ & 2 & c. $241 \mathrm{G}>\mathrm{A}$ & p.E81K & This study \\
\hline 16 & РССВ & 3 & c. $337 \mathrm{C}>\mathrm{T}$ & p.R113* & \\
\hline 17 & РССВ & 3 & c. $331 \mathrm{C}>\mathrm{T}$ & p.R111X & This study \\
\hline $18^{*} \mathrm{sib}$ of 19 & РССВ & 3 & c.304_304delT & p.P103Lfs*24 & This study \\
\hline $19 *$ sib of 18 & РССВ & 3 & c.304_304delT & p.P103Lfs*24 & This study \\
\hline $20^{*} \mathrm{sib}$ of 21 & PCCA & 22 & c. $2041-2 A>G$ & IVS22-2A>G & \\
\hline $21^{*}$ sib of 20 & PCCA & 22 & c. $2041-2 A>G$ & IVS22-2A>G & \\
\hline $22 *$ cousin of 23 & РCCB & 7 & c. $764 \_2 A>G$ & IVS7-2A $>G$ & This study \\
\hline $23^{*}$ cousin of 22 & РCCB & 7 & c.764_2A > G & IVS7-2A $>G$ & This study \\
\hline 24 & РCCB & 15 & c. $1600 \mathrm{C}>\mathrm{T}$ & p.R534* & \\
\hline 25 & РCCB & 11 & c.1050insT & p.E351* & \\
\hline 26 & РCCB & 3 & c. $337 \mathrm{C}>\mathrm{T}$ & p.R113* & \\
\hline 27 & РССВ & 1 & c. $183+5 \mathrm{G}>\mathrm{T}$ & $\mathrm{IVS} 1+5 \mathrm{G}>\mathrm{T}$ & This study \\
\hline
\end{tabular}

of authors reported neurological problems slightly more frequent as $77 \%, 83 \%$ and $91 \% .^{11,14-15} \quad$ Neurological symptoms like hypoactivity, lethargy, and seizures were present in $40 \%$ of our patients. Eleven \% of our patients had seizures. However, occurrence rate of seizures was as high as $43 \%$ in some reports. ${ }^{14}$

Although the median age at onset of symptoms was 3 days, diagnosis was made at a median age of 35.5 days (range from prenatal-10.5 year). Another study reported 12 days apart from those diagnosed with the $\mathrm{NSP}^{13}$. In another study, clinical manifestations were reported to occur in the first week in $84 \%$ and the first 2 weeks of life in $92 \%$ of patients. ${ }^{11}$ In this study, median age at diagnosis is later than the reported in the literature because the time interval between the onset of symptoms and the admission to hospital is longer in our patient population.

The mortality rate was found to be $37 \%$ in our study. In a similar study 42 early-onset PA patients were included and mortality rate 
was reported to be $33 \% .{ }^{9}$ In another study, mortality rate was reported as $90 \%$ up to 6 years. ${ }^{16}$ Whereas, in a study, involving patients diagnosed with NSP, mortality rate was reported as $8 \% .{ }^{13}$ This clearly shows that early diagnosis of PA through NSP is associated with a tendency toward lower mortality rates.

In our study, we identified 12 different mutations in the $P C C B$ gene and 8 different mutations in the PCCA gene. Further, we identified seven mutations in $P C C B$ gene and five mutations in PCCA gene, that had not previously been published. Our study shows the predominance of $P C C B$ gene mutations, in similarity with other studies, although we have a relatively small patient cohort. ${ }^{12,17-19}$ On the contrary, some other studies showed a higher percentage of PCCA gene mutations. $^{20-22}$ No single common mutation was identified in both genes. A large number of novel mutations was detected in our study $(60 \%)$. The variety of mutations may suggest the highly heterogeneous nature of genotype of PA in Turkey. The study included patients from the south and southeast parts of Turkey. This geographical region has the highest rates of parental consanguinity in Turkey. Patients included in this study were from different socioeconomic status and ethnicities. So, this cohort may not reflect the entire country therefore this may be the limitation of this study. Further multicentre, longitudinal studies are needed to better elucidate the clinical spectrum of the disease. Lack of NSP and delay in diagnosis seem to be major factors associated with poor outcomes and increased mortality of children in the present study.

In this study, we report the clinical and molecular characteristics of 27 Turkish patients which provides additional knowledge to the genotype and phenotype of PA. Our data suggest that PCCA and $P C C B$ mutations in Turkish populations are distinct from other populations. Genetic heterogeneity was observed in our cohort in spite of the high rate of consanguineous marriages in Turkey, which are considered to be an important factor contributing to the higher incidences of autosomal recessive hereditary diseases. In addition, seven novel mutations in the $P C C B$ gene and five novel mutations in the PCCA gene were identified, and therefore expand the mutational spectrum of these $P C C A-P C C B$ genes.

\section{REFERENCES}

1. Hsia YA, Scully KJ, Rosenberg LE. Inherited propionyl-CoA carboxylase deficiency in "ketotic hyperglycinemia”. J Clin Invest 1971; 50: 127-130.

2. Fenton WA, Gravel RA, Rosenblatt DS. Disorders of propionate and methylmalonate metabolism. In: Scriver C, Beaudet A, Sly W, Valle D (eds.) The Metabolic and Molecular Bases of Inherited Disease. New York: McGraw-Hill, 2001; 2165-2190.

3. Huang CS, Sadre-Bazzaz K, Shen Y, Deng B, Zhou $\mathrm{ZH}$, Tong L. Crystal structure of the alpha (6) beta (6) holoenzyme of propionyl-coenzyme A carboxylase. Nature 2010; 466: 1001-1005.

4. Lamhonwah AM, Barankiewicz TJ, Willard HF, Mahuran DJ, Quan F, Gravel RA. Isolation of cDNA clones coding for the alpha and beta chains of human propionyl-CoA carboxylase: chromosomal assignments and DNA polymorphisms associated with PCCA and PCCB genes. Proc Natl Acad Sci U S A. $1986 ; 83: 4864-4868$.

5. Chapman KA, Bush WS, Zhang Z. Gene expression in cell lines from propionic acidemia patients, carrier parents, and controls. Mol Genet Metab 2015; 115: 174-179.

6. Sutton VR, Chapman KA, Gropman AL, et al. Chronic management and health supervision of individuals with propionic acidemia. Mol Genet Metab 2012; 105: 26-33.

7. Baumgartner MR, Horster F, Carlo Dionisi-Vici, et al. Proposed guidelines for the diagnosis and management of methyl-malonic and propionic acidemia. Orphanet J Rare Dis 2014; 9: 130.

8. Pena L, Franks J, Chapman KA, et al. Natural history of propionic acidemia. Mol Genet Metab 2012; 105: $5-9$.

9. Sass JO, Hofmann M, Skladal D, Mayatepek E, Schwahn B, Sperl W. Propionic acidemia revisited: a workshop report. Clin Pediatr (Phila) 2004; 43: 837 843.

10. Van der Meer SB, Poggi F, Spada M, et al. Clinical outcome and long-term management of 17 patients with propionic acidaemia. Eur J Pediatr 1996; 155: 205-210.

11. Rafique M. Clinical Spectrum of Propionic Acidaemia. J Nutr Metab 2013; 1-6.

12. McCrory NM, Edick MJ, Ahmad A, et al; Inborn Errors of Metabolism Collaborative. Comparison of methods of initial ascertainment in 58 cases of propionic acidemia enrolled in the Inborn Errors of Metabolism Information System reveals significant differences in time to evaluation and symptoms at presentation. J Pediatr 2017; 180: 200-205.e8. 
13. Grünert SC, Müllerleile S, de Silva L, et al. Propionic acidemia: neonatal versus selective metabolic screening. J Inherit Metab Dis 2012; 35: 41-49.

14. Lehnert W, Sperl W, Suormala T, Baumgartner ER. Propionic acidaemia: clinical, biochemical and therapeutic aspects. Experience in 30 patients. Eur J Pediatr 1994; 153(Suppl 1): S680S80.

15. Walter JH, Wraith JE, and Cleary MA. Absence of acidosis in the initial presentation of propionic acidaemia. Arc DisChild Fetal Neonatal Ed 1995; 72: F197-199.

16. Surtess RA, Matthews EE, Leonard JV. Neurologic outcome of propionic acidemia. Pediatr Neurol 1992; 8: 333-337.

17. Kraus JP, Spector E, Venezia S, et al. Mutation analysis in 54 propionic acidemia patients. J Inherit Metab Dis 2012; 35: 51-63.

18. Desviat LR, Perez B, Perez-Cerda C, RodríguezPombo P, Clavero S, Ugarte M. Propionic acidemia: mutation update and functional and structural effects of the variant alleles. Mol Genet Metab 2004; 83: 28 37.
19. Perez B, Desviat LR, Rodriguez-Pombo P, et al Propionic acidemia: identification of twenty-four novel mutations in Europe and North America. Mol Genet Metab 2003; 78: 59-67.

20. Gupta D, Bijarnia-Mahay S, Kohli S, et al. Seventeen Novel Mutations in PCCA and PCCB Genes in Indian Propionic Acidemia Patients, and Their Outcomes. Genet Test Mol Biomarkers 2016; 20: 373-82.

21. Chen Z, Wen P, Wang G, et al. Analysis of PCCA and PCCB gene mutations in patients with propionic acidemia. Zhonghua Yi Xue Yi Chuan Xue Za Zhi 2015; 32: 26-30.

22. Vatanavicharn N, Liammongkolkul S, Sakamoto O, Kamolsilp M, Sathienkijkanchai A, Wasant P. Clinical characteristics and mutation analysis of propionic acidemia in Thailand. World J Pediatr 2014; 10: 6468. 